\title{
Digital Games Based Language Learning for Arabic Literacy Remedial
}

\section{Noor Azli Mohamed Masrop', Hafawati Ishak, Ghazali Zainuddin², Siti Rosilawati Ramlan³, Muhammad Sabri Sahrir4, Harwati Hashim ${ }^{\text {* }}$}

\author{
${ }^{1}$ Faculty of Science and Information Technology, Kolej Universiti Islam (KUIS), Antarabangsa Selangor, Malaysia \\ ${ }^{2}$ Faculty of Islamic Studies and Civilization, KUIS, Antarabangsa Selangor, Malaysia \\ ${ }^{3}$ Faculty of Education, International Islamic University Malaysia (IIUM), Gombak, Selangor, Malaysia \\ ${ }^{4}$ Faculty of Major Language Studies, Islamic Science University of Malaysia (USIM), Nilai, Negeri Sembilan, Malaysia \\ ${ }^{5}$ Faculty of Education, Universiti Kebangsaan Malaysia, Bangi, Malaysia \\ Email: noorazli@kuis.edu.my, harwati@ukm.edu.my
}

How to cite this paper: Masrop, N. A. M., Ishak, H., Zainuddin, G., Ramlan, S. R., Sahrir, M. S., \& Hashim, H. (2019). Digital Games Based Language Learning for Arabic Literacy Remedial. Creative Education, 10, 3213-3222.

https://doi.org/10.4236/ce.2019.1012245

Received: October 18, 2019

Accepted: November 27, 2019

Published: November 30, 2019

Copyright (c) 2019 by author(s) and Scientific Research Publishing Inc. This work is licensed under the Creative Commons Attribution International License (CC BY 4.0).

http://creativecommons.org/licenses/by/4.0/

\begin{abstract}
Digital gameplay is becoming increasingly prevalent. Its participant-players number in the millions and its revenues are in billions of dollars. As they grow in popularity, digital games are also growing in complexity, depth and sophistication. This paper presents reasons why games and gameplay matter to the future of education. Drawing upon these works, the potential for instruction in digital games is recognized. Previous works in the area were also analyzed with respect to their theoretical findings. Hence, the authors in this study propose some existing Arabic language learning games intended for education of children. The analysis result shows that the majority of Arabic language learning games are limited to alphabet content. The overall presentation lacks of quality in terms of graphics, animations, colors and voice-over.
\end{abstract}

\section{Keywords}

Digital Gameplay, Educational Games, Arabic Language, DGBLL Model, Gamification

\section{Introduction}

Children spend many of their waking hours engaged in play (Lillard, 2015). Play contributes to cognitive development in a number of ways. It helps children to develop imaginary and memory which is essential for thinking about past, present and future (Ahmad, Ch, Batool, Sittar, \& Malik, 2016). They play games in classes, in their off-hours, even as part of their private contemplation. There is a growing body of literature that recognizes the importance of games in children 
students' lives. Over the last several decades, new technologies have allowed digital media to create a multibillion-dollar entertainment industry commonly known as computer video and digital games.

In 2016, the U.S. computer and video game industry generated $\$ 30.4$ billion in revenue, according to new data released by the Entertainment Software Association (ESA) and the NPD Group. This is total consumer spend figure that includes revenues from all hardware, software, peripherals, and in-game purchases Separately, ESA highlighted that video game software revenue grew 6 percent from the 2015 level. In 2016, video game software revenue which includes physical packaged goods, mobile games, downloadable content, subscriptions and other revenue streams, reached $\$ 24.5$ billion up from 23.2 billion in 2015. Sales in the US digital games market had grown from $\$ 43.3$ billion in revenue in 2018, up to 18 percent from 2017 (The ESA, 2019-b). Furthermore, retail sales of video games in US reached a record US\$7.4 billion in 2004.

In 2004, Malaysia's online gaming market was worth US\$7 million in subscription revenue in 2019 up to 2 percent in 2018 (Statista, 2019). These statistics don't yet include other types of games (non-online) that are pirated. The original game software market in Malaysia is almost non-existent due to the piracy of most game software in the market. As an example, Malaysian Ministry of Domestic Trade and Consumer Affairs' (MDTCA) has seized more than 110,000 copies of pirated computer and video games in a raid on one illegal duplication lab, which is capable of duplicating 2.4 million pirated discs per year. Looking at the seized volume of pirated software, we can presume that there are many digital games players locally (Entertainment Software Association (IGN, 2008). The digital games industry is a multi-billion dollar industry, with games being developed for a variety of platforms, devices and emerging technologies.

Educators and trainers have looked at the multi-billion dollar computer and video game industry for inspiration. While the primary purpose of games is entertainment, the underlying design employs a variety of strategies and techniques intended to engage players in gameplay. The traditional school finds, at present, difficulties to maintain the concentration of the student and to foment its desire to learn. Faced with this reality, the use of educational games is one of the ways to motivate the student to participate actively in the activities (Bürger \& Ghisleni, 2019). This paper discusses the various aspects of digital games with a view to using this powerful medium to support children's language learning.

\section{The Games}

Games are a difficult concept to define. To date, computer games researchers are still debating the definition of games; the entry of educators into the fray complicates matters further (Noor, 2014). However, in this paper, the terms "digital game", "mobile game", "computer games" and "video games" are defined as digital applications that can be controlled by individuals or groups of players using a phone, tablet, computer or a video/console such as PlayStation or Xbox ma- 
chine.

Digital games are today an important part of most children's leisure and are increasingly becoming an important part of our culture as a whole. According to Entertainment Software Association (ESA), 28\% of game players are children under 18 years old in USA (The ESA, 2019-a). Hence certain features of games can be adopted to make learning interesting and rewarding for children.

Therefore, educational games have become a research focus which studied how players learn some knowledge while they play in a game environment. For instant, Nor Azan, Azizah and Wong (2009) had studied the potential use of educational games in teaching history as a boring subject as perceived by students and teachers.

\subsection{Digital Games-Based Language Learning (DGBLL)}

The use of educational games have attracted researchers' attention from around the world and perceived as an integrated tool within the teaching and learning process (Prensky, 2001a; Whitton, 2010) with various terms such as "game-based learning" or GBL (Prensky, 2001b), "edutainment" and "serious games" (Tsai et al., 2008), and gamification (Hee \& Jae, 2014). In addition, the gamification term is used in education as a process of applying elements of the game in conveying knowledge to students. The term gamification first triggered in 2002 by the creators of the game of Briton, Nick Pelling and it became widely used in 2010 (Kamasheva, 2015).

Recent interest in games and learning stems from debates about the role and practices of education in a new century, rather than from belief that young people find games motivating and fun, therefore, they should be exploited in educational contexts.

Definitions of game-based learning mostly emphasize that is a type of game play with defined learning outcomes (Plass, Homer, \& Kinzer, 2015). According to Cheng and Whang (2019) digital game-based learning (DGBLL) refers to the learning approach that incorporates educational content or learning designs into digital games. Research is mainly concerned with the development of related competencies and literacies during game play, the role of games in the formation of learning communities either while gaming, or related to gameplay.

We need to create both a good game as well as a good learning experience. This can be achieved by either creating a game for the purpose from scratch or adapting an existing game to fit into an educational framework (Andreassen, 2015). But according to Chen et al., (2018) the literature still appears to lack a systematic framework for guiding the integration of language learning with contextual game-based environments.

The positive impact and instructional advantages of DGBLL materials over printed course materials have been reported in relation to improvements in learners' listening skills (Bernert-Rehaber \& Schlemminger, 2013; Roy \& Schlemminger, 2014), in vocabulary knowledge (Kocaman \& Cumaoglu, 2014) and writ- 
ing skills (Levy \& O’Brien, 2006; Neville, Shelton, \& McInnis, 2009) in communication, grammatical accuracy and writing skills (Berns, Palomo-Duarte, Dodero, \& Valero-Franco, 2013) and in learners' general fluency, pronunciation and reading skills in the target language (Bernert-Rehaber \& Schlemminger, 2013). Along with language skills, positive results have also been reported in raising learners' intercultural awareness and intercultural communicative competence (Guillén-Nieto \& Aleson-Carbonell, 2012; Levy \& O’Brien, 2006) because serious games provided learners an invaluable opportunity to truly experience the target culture.

\subsection{Categories of Games}

There have been many attempts to classify games. For example Ramsi (2015) classify games using generic descriptors of the current popular types, which include 1) action, 2) adventure, 3) strategy, 4) simulation, 5) shooter, 6) sports, 7) role-playing, 8) puzzle games and 9) board game (Hee \& Jae, 2014). However these categories are not mutually exclusive. Many games fall into more than one category (Prensky, 2001), such as being both adventure and combat games.

Based on the statistical results reported in 113 reviewed papers, Chang and Hwang (Chang \& Hwang, 2019) suggest that, for those new researchers who intend to adopt the mobile gaming approach, the three most frequently adopted game types (i.e., simulation game, role-play game and gamification) can be considered first.

\section{Why Do People Play Games?}

Research on the motivations for games playing has been carried out across a number of disciplines. Being able to scrutinize the aspects of motivating play is important for designing games and gamified systems since the main purpose of gamely interaction is essentially to provide motivational affordances (Koivisto \& Hamari, 2014).

Thomas Malone (1980) identified three main ways in which games were able to motivate players: fantasy, challenge and curiosity. A survey by ESA found three main reasons for gameplay: 1) connect them with their friends (55\%), 2) it helps their family spend time together $(46 \%), 3$ ) provides mental stimulation or education (75\%) (Entertainment Software Association, 2019).

In the US, most of the children gameplay was supported by parents. Four main reasons parents play games with their children are fun for the entire family (88\%), they're asked to (76\%), good opportunity to socialize with the child (76\%) and a good opportunity to monitor game content (59\%) (Sanela \& Loretta, 2015).

Presumably the fact that something does happen encourage players to proceed, and the quality of what happens in terms of user engagement is the factor that keeps them playing (Kirriemuir \& Mcfarlane, 2004). It was suggested that the degree of difficulty of gameplay is important for children to enjoy playing 
and the game must be neither too difficult nor too easy (McFarlane, Sparrowhawk, \& Heald, 2002).

\section{Games and Children}

Game approach in education or playing while learning is in the Malaysian preschool curriculum (Pusat Perkembangan Kurikulum, 2001). Various researches on children gameplay have been carried out. Systematic literature review of research studies on game-based learning and gamification conducted in Asian K-12 schools, that conducted by So and Seo (2018) have shown that the reviewed articles advocated the positive efficacy of games on learning outcomes.

Vasalou, Khaled, Holmes, and Gooch, (2017) apply a social constructivist lens to DGBL for children who struggle with literacy. The findings show that children spontaneously engage in "game talk" regarding game performance, content, actions and experiences. While this game talk facilitates a strong sense of social engagement and playfulness, it also caters to a variety of new opportunities for learning by sparking tutor and student-initiated interventions.

Ismail, Hashim, Anis, Ismail, \& Ismail (2017) carried out the research about document analysis that focus on game, emotional, cognitive and psychomotor element based on standard curriculum blueprint for early childhood education. The result shows that the developmental elements applied in the game were suitable with the preschool students age and it can achieve the objectives that outlined by the National Preschool Curriculum Standard.

In terms of the use of board game as gamification tool in teaching and learning, the studies have shown that the respondents agree that the board game can be used as an effective learning edutainment tool for in enhancing knowledge theoretically and practically at higher level learners (Azman, Ab. Rahman, et. al, 2018) or school children at primary level (Nurkhamimi, Zainuddin, et. al., 2019)

\section{Arabic Language Leaning}

Although Arabic has been studied as subjects in primary and secondary schools, a large number of students in Malaysia still cannot speak Arabic. Awang, Mohamed, and Sulaiman (2013) state that students do not have the confidence to use Arabic in and out of the classroom. According to Ghani et al., (Ghani et al., 2019) the weakness of the Arabic language has resulted in the impairment of the quality of teaching and learning of Arabic language in schools in Malaysia.

Researchers have identified that among the problems faced by students in Arabic learning or other second language is related to the vocabulary (Ghani et al., 2019; Aladdin, 2012).

\subsection{Arabic Vocabularies Leaning}

Vocabulary is an important aspect in language because it is the first step in learning any language. Without vocabulary, learning language skills such as listening, speaking, reading and writing cannot be realized successfully (Alobaydi, 
Alkhayat, Arshad, \& Ahmed, 2017). In other words, vocabulary is an essential part of language and it is the first step in learning any language. Ashinida (Aladdin, 2012) and Ghazali et al. (Yusri, Rahimi, Shah, \& Wah, 2013a) verified that poor knowledge of Arabic vocabulary limits the ability of students to communicate, write, read and listen to materials in Arabic.

Therefore, Noor et al., (Noor, Yusoff, Yasim, \& Kamarudin, 2016) state that in order to encourage students to learn Arabic, teachers need to introduce interesting learning strategies such as independent and active learning through the use of electronic materials. Thus, the focus is on learning Arabic vocabulary only as a first step in learning Arabic language through digital games that provides more convenient and attractive learning process.

\subsection{Digital Games Based Arabic Language Learning}

A huge number of studies have been devoted to various fields. Digital games based learning (DGBL) in the field of language education has been widely used due to their positive outcomes in learning and learner participation. Usability, motivation, flow state, affective engagement, and learning were determined, which revealed that serious games were frequently used with a high level of engagement. However, there are not many relevant DGBL studies in the context of Arabic language learning. There are few games for learning Arabic dedicate to children. Generally they are simplistic and tend to revolve around the same trivial idea in language learning (Ramsi, 2015).

Sahrir, MS, \& Alias, NA (2012) reported a positive perception of university students in learning Arabic online. To ensure the effectiveness of using digital games in education, there are three main components that should be considered: 1) Pedagogy 2) DGBL elements 3) ARCS model. There are some existing online games that teach Arabic language to children like ALADDIN, Salaam Arabic, and Araboh.com. Although they showed success for children, they do not address the Learning Disabilities (LDs) or the intellectual problems (Salah, Abdennadher, Sabty, \& Abdelrahman, 2016).

In addition, Hamizul and Nik Rahimi had identified the potential of merging games elements, pedagogy components and ARCS model to suit Arabic online games model in a web-based platform. While Siti Rohani, Suhaila and Hakim have discussed the potential of using gamification approach in learning Arabic language.

\subsection{Analysis of Some Existing Games}

The authors have reviewed some existing Arabic Language Learning games intended for education of children and chose the following games: Arabic Games: Word and Vocabulary, Arabic Alphabet Kids, Secil Bahasa Arab, and Bee Learning Arabic. Table 1 describes their major characteristics (Table 2).

\section{Conclusion}

This paper discusses the digital games and their potential use in supporting 
Table 1. Descriptions of Arabic educational games.

\begin{tabular}{cl}
\hline \multicolumn{1}{c}{ Game name } & \multicolumn{1}{c}{ Description } \\
\hline Arabic Games (AGW) & $\begin{array}{l}\text { The players only have multiple choice questions. Player can learn and } \\
\text { play with 40 level with different task). }\end{array}$ \\
$\begin{array}{c}\text { Arabic Alphabet Kids } \\
\text { (AAK) }\end{array}$ & $\begin{array}{l}\text { The players provide teaching Arabic alphabet but also to read and write } \\
\text { basic words using the names and sounds of animal. }\end{array}$ \\
$\begin{array}{cl}\text { Secil Bahasa Arab (SBA) } \\
\text { - } \begin{array}{l}\text {-This game provides: four module to learn and games to practice the } \\
\text { module, voice and shape to learn. (androidappapk.co, 2018) }\end{array} \\
\text { (BLA) }\end{array}$ & $\begin{array}{l}\text {-This game gives the player to know and learn alphabet and provide } \\
\text { guide for players (X-Gaf Studio, 2018) }\end{array}$ \\
\hline
\end{tabular}

Table 2. Content analysis of Arabic educational games.

\begin{tabular}{cccccc}
\hline Game name & Content $^{(\mathrm{i})}$ & $\begin{array}{c}\text { Organization }^{(\mathrm{ii})} \\
\text { of the contents }^{(\text {Interactivity }}\end{array}$ & Graphics $^{(\mathrm{iiv})}$ & Assessment $^{(\mathrm{v})}$ \\
\hline AGW & 2 & 2 & 2 & 2 & 1 \\
AAK & 1 & 1 & 1 & 1 & 2 \\
SBA & $1,2,3$ & 2 & 1 & 1 & $1,2,3$ \\
BLA & 1 & 1 & 2 & 3 & 1 \\
\hline
\end{tabular}

Notes: (i) Content: (1) Alphabet, (2) Words, (3) Numbers, (4) Pronunciation, (5) sentence, (6) Grammar; (ii) Organization of the contents: (1) Randomly, (2) Organized; (iii)Interactivity: (1) Sounds guide the player, (2) Boring; ${ }^{\text {(iv) }}$ Graphic (1) Colorful (2) Moderate (3) Poor; ${ }^{(v)}$ Assessment: (1) Multiple choice (2) Puzzle (3) Guessing.

learning. Games can provide powerful learning environments, especially for children. We also analyze some existing games. The analysis result shows that the majority of Arabic Language learning games are limited to alphabet content. The overall presentation lacks quality in terms of graphics, animations, colors, and voice-over. Moreover, none of Arabic games shows a systematic design process. They do not have the ability to engage the learner in the game.

\section{Acknowledgements}

The authors wish to thank KUIS, Selangor State Government which has supported this research under GPPSTI Grant Scheme (GPPSTI) and Grant code PP-FPEND-2019.

\section{Conflicts of Interest}

The authors declare no conflicts of interest regarding the publication of this paper.

\section{References}

Ahmad, S., Ch, A. H., Batool, A., Sittar, K., \& Malik, M. (2016). Play and Cognitive Development: Formal Operational Perspective of Piaget's Theory. Journal of Education and Practice, $7,72-79$.

Aladdin, A. (2012). Analisis penggunaan strategi komunikasi dalam komunikasi lisan 
Bahasa Arab. GEMA Online Journal of Language Studies, 12, 645-666.

Alobaydi, E. K., Alkhayat, R. Y., Arshad, M. R. M., \& Ahmed, E. R. (2017). Context-Aware Ubiquitous Arabic Vocabularies Learning System (U-Arabic): A Framework Design and Implementation. In 2017 th IEEE International Conference on Control System, Computing and Engineering (ICCSCE) (pp. 23-28). Penang, Malaysia. https://doi.org/10.1109/ICCSCE.2017.8284373

Andreassen, S. (2015). Zombies in the Classroom. Video Games for Engagement in a New Century of Education. Bergen: The University of Bergen.

Awang, N. A., Mohamed, M. H., \& Sulaiman, R. (2013). Enhancing Arabic Speaking Skills among Malay Students through Group Work Activities. International Journal of Humanities and Social Science, 3, 212-219.

Azman, A. R., Sahrir, M. S., Zainuddin, N., \& Abd Khafidz, H. (2018). Evaluating Global Zakat Game (GZG) Board Game in Enhancing Zakat Education. Journal of Education and Learning, 12, 568-574.

Bernert-Rehaber, S., \& Schlemminger, G. (2013). Immersive 3D-Technologien optimieren das Fremdsprachenlernen: EVEIL-3D-Lernen in virtuellen Welten. Babylonia, 3, 44-49.

Berns, A., Palomo-Duarte, M., Dodero, J. M., \& Valero-Franco, C. (2013). Using a 3D Online Game to Assess Students' Foreign Language Acquisition and Communicative Competence. In D. Hernández-Leo, T. Ley, R. Klamma, \& A. Harrer (Eds.), European Conference on Technology Enhanced Learning (pp. 19-31). Heidelberg: Springer. https://doi.org/10.1007/978-3-642-40814-4 3

Bürger, C. A. C., \& Ghisleni, T. S. (2019). Education and Games: Educomunicative Analysis on the Implementation of Games in Teaching Environments. Research, Society and Development, 8, Article ID: 4684900. https://doi.org/10.33448/rsd-v8i4.900

Chang, C. Y., \& Hwang, G. J. (2019). Trends in Digital Game-Based Learning in the Mobile Era: A Systematic Review of Journal Publications from 2007 to 2016. International Journal of Mobile Learning and Organization, 13, 68-90. https://doi.org/10.1504/IJMLO.2019.096468

Chen, Z. H., Chen, H. H. J., \& Dai, W.-J. (2018). Using Narrative-Based Contextual Games to Enhance Language Learning: A Case Study. Journal of Educational Technology \& Society, 21, 186-198.

Entertainment Software Association (2019). 2018 Sales, Demographic, and Usage Data Essential Facts about the Computer and Video Game Industry. http://www.theesa.com/wp-content/uploads/2018/05/EF2018 FINAL.pdf

Ghani, M. T. A., Hamzah, M., Ramli, S., Ab, W., Daud, A. W., Romli, T. R. M., \& Mokhtar, N. N. M. (2019). A Questionnaire-Based Approach on Technology Acceptance Model for Mobile Digital Game-Based Learning. Journal of Global Business and Social Entrepreneurship (GBSE), 5, 11-21.

Guillén-Nieto, V., \& Aleson-Carbonell, M. (2012). Serious Games and Learning Effectiveness: The Case of It's a Deal! Computers \& Education, 58, 435-448. https://doi.org/10.1016/j.compedu.2011.07.015

Hee, J. P., \& Jae, H. B. (2014). Study and Research of Gamification Design. The International Journal of Software Engineering \& Applications, 8, 19-28.

IGN (2008). Malaysian Authorities Shut Down Pirate Game Lab. The Entertainment Software Association Website.

https://www.ign.com/articles/2008/02/07/malaysian-authorities-shut-down-pirate-gam $\underline{\mathrm{e}-\mathrm{lab}}$ 
Ismail, I. M., Hashim, S., Anis, S. K., Ismail, A., \& Ismail, M. E. (2017). Implementation of a Development in Cognitive, Psychomotor and Socio Emotional Elements through Games to Achieve National Preschool Curriculum Standards. In 2017 IEEE 9th International Conference on Engineering Education (ICEED) (pp. 143-148). Kanazawa, Japan. https://doi.org/10.1109/ICEED.2017.8251182

Kamasheva, A. V. (2015). Usage of Gamification Theory for Increase Motivation of Employees. Mediterranean Journal of Social Sciences, 6, 77-80. https://doi.org/10.5901/mjss.2015.v6n1s3p77

Kirriemuir, J., \& Mcfarlane, A. (2004). Literature Review in Games and Learning. https://telearn.archives-ouvertes.fr/hal-00190453

Kocaman, O., \& Cumaoglu, G. K. (2014). The Effect of Educational Software (DENIS) and Games on Vocabulary Learning Strategies and Achievement. Egitim ve Bilim, 39, 305-316.

Koivisto, J., \& Hamari, J. (2014). Demographic Differences in Perceived Benefits from Gamification. Computers in Human Behavior, 35, 179-188. https://doi.org/10.1016/j.chb.2014.03.007

Levy, R. M., \& O’Brien, M. G. (2006). A Virtual World for Teaching German. Loading, 1, 1-17.

Lillard, A. S. (2015). The Development of Play. In Handbook of Child Psychology and Developmental Science (pp. 1-44). London: Wiley. https://doi.org/10.1002/9781118963418.childpsy211

Malone, T. W. (1980). What Makes Things Fun to Learn? A Study of Instrinsically Motivating Computer Games. https://doi.org/10.1145/800088.802839

McFarlane, A., Sparrowhawk, A., \& Heald, Y. (2002). Report on the Educational Use of Games. Cambridge: TEEM (Teachers Evaluating Educational Multimedia).

Neville, D. O., Shelton, B. E., \& McInnis, B. (2009). Cybertext Redux: Using Digital Game-Based Learning to Teach L2 Vocabulary, Reading, and Culture. Computer Assisted Language Learning, 22, 409-424. https://doi.org/10.1080/09588220903345168

Noor Azli, M. M. (2014). Pembelajaran Berasaskan Permainan Digital (Pbpd) Bagi Pendidikan Literasi Jawi Berasaskan Model Motivasi. Bangi: Universiti Kebangsaan Malaysia.

Noor, Z. A. M., Yusoff, N. M. R. N., Yasim, I. M. M., \& Kamarudin, M. Y. (2016). Foreign Language Vocabulary Learning Strategies in Malaysia. Creative Education, 7, 428-434. https://doi.org/10.4236/ce.2016.73042

Plass, J. L., Homer, B. D., \& Kinzer, C. K. (2015). Foundations of Game-Based Learning. Educational Psychologist, 50, 258-283. https://doi.org/10.1080/00461520.2015.1122533

Prensky, M. (2001a). Digital Game-Based Learning. New York: Paragon House.

Prensky, M. (2001b). Digital Game-Based Learning. New York: McGrawHill.

Pusat Perkembangan, K. (2001). Kurikulum prasekolah kebangsaan. Malaysia: Kementerian Pendidikan Malaysia.

Ramsi, F. M. A. (2015). A Game-Based Learning Model. Abu Dhabi: United Arab Emirates University.

Roy, M., \& Schlemminger, G. (2014). Immersion und interaktion in virtuellen realitäten: Der faktor präsenz zur optimierung des geleiteten sprachenlernens. Zeitschrift Für Interkulturellen Fremdsprachenunterricht, 19, 187-201.

Salah, J., Abdennadher, S., Sabty, C., \& Abdelrahman, Y. (2016). Super Alpha: Arabic Alphabet Learning Serious Game for Children with Learning Disabilities. In Joint Inter- 
national Conference on Serious Games (pp. 104-115). Cham: Springer. https://doi.org/10.1007/978-3-319-45841-0 9

Sanela, O., \& Loretta, P. (2015). Beyond Entertainment: Motivations and Outcomes of Video Game Playing by Older Adults and Their Younger Family Members. Games and Culture, 11, 130-149. https://doi.org/10.1177/1555412015602819

So, H. J., \& Seo, M. (2018). A Systematic Literature Review of Game-Based Learning and Gamification Research in Asia. In K. J. Kennedy, \& J. C. K. Lee (Eds.), Routledge International Handbook of Schools and Schooling in Asia. Abingdon: Routledge.

Statista (2019). Online Games-Malaysia. Statista Market Forecast. https://www.statista.com/outlook/212/122/online-games/malaysia

The ESA (2019a). U.S. Average Age of Video Gamers 2018. Statistic. https://www.statista.com/statistics/189582/age-of-us-video-game-players-since-2010/

The ESA (2019b). U.S. Video Game Sales Reach Record-Breaking \$43.4 Billion in 2018. The Entertainment Software Association Website.

http://www.theesa.com/press-releases/u-s-video-game-sales-reach-record-breaking-434-billion-in-2018/

Tsai, F. H., Yu, K. C., \& Hsiao, H. S. (2008). A Pilot Study of Comparing the Effectiveness in Game-Based and Web-Based Learning.

http://www.ntnu.edu.tw/acad/docmeet/96/a16/a1601.pdf

Vasalou, A., Khaled, R., Holmes, W., \& Gooch, D. (2017). Digital Games-Based Learning for Children with Dyslexia: A Social Constructivist Perspective on Engagement and Learning during Group Game-Play. Computers \& Education, 114, 175-192. https://doi.org/10.1016/j.compedu.2017.06.009

Whitton, N. (2010). Learning with Digital Game, a Practical Guide to Engaging Students in Higher Education. New York and London: Routledge Taylor \& Francis Group. https://doi.org/10.4324/9780203872987

X-Gaf Studio (2018). Bee Learning Arabic Kids-Apl di Google Play. https://play.google.com/store/apps/details?id=air.beearabicalphabet\&hl=ms

Yusri, G., Rahimi, N. M., Shah, P. M., \& Wah, W. H. (2013). Cognitive and Metacognitive Learning Strategies among Arabic Language Students. Interactive Learning Environments, 21, 290-300. https://doi.org/10.1080/10494820.2011.555840 